\title{
COMMENT
}

\section{SECTION 13(d) AND DISCLOSURE OF CORPORATE EQUITY OWNERSHIP}

The Williams Act, passed by Congress in 1968, was entitled "An Act [p] roviding for full disclosure of corporate equity ownership of securities under the Securities Exchange Act of 1934." At the time, few understood the Act to be anything other than a law requiring disclosure of information by those who attempt to gain control of a corporation through a device known as the tender offer. ${ }^{2}$ The Act was broader, however, amending the Securities Exchange Act of $1934^{3}$ by adding sections 13 (d) and (e), as well as the tender offer provisions in sections $14(d),(e)$, and (f)..$^{4}$ Section $13(d)$ established a searching disclosure requirement for persons who become direct or indirect beneficial owners of more than ten percent of any equity security registered under section 12 of the Exchange Act, ${ }^{5}$ subject to certain exemptions. ${ }^{6}$

1 Act of July 29, 1968, Pub. L. No. 90-439, 82 Stat. 454, amending Securities Exchange Act $\$ \$ 12-14,15$ U.S.C. $\$ \$ 78 l$-n (1964).

2 The term tender offer generally refers to a solicitation of shareholders of an issuer to tender their shareholdings to the party making the offer. The offeror's consideration may be expressed either in cash or in other securities, giving rise to the terms "cash tender offer" and "stock tender offer." While the former is commonly referred to as simply a "tender offer" and the latter as an "exchange offer," the Williams Act used the term "tender offer" in \$14(d) without definition and then exempted offers made "by means of a registration statement under the Securities Act of 1933," namely situations where the consideration was another security. $\$ 14$ (d) (B) (A), 15 U.S.C. $\$ 78 n(d)(8)(A)$ (Supp. V, 1970). Discussions of cash tender offers are numerous and exhaustive, both before the Williams Act, e.g., Fleischer \& Mundheim, Corporate Acquisition by Tender Offer, 115 U. PA. L. Rev. 317 (1967) ; Hayes \& Taussig, Tactics of Cash Takeover Bids, HARv. Bus. Rev., Mar.-Apr. 1967, at 135; Swanson, S. 510 and the Regulation of Cash Tender Offers: Distinguishing St. George from the Dragon, 5 HARV. J. LEGrs. 431 (1968), and after, e.g., Schmults \& Kelly, Disclosure in Connection with Cash Take-over Bids: The Nez Regulations, 24 Bus. LAw. 19 (1968); Note, Cash Tender Offers, 83 HARv. L. Rev. 377 (1969). The Act of Dec. 22, 1970, Pub. L. No. 91-567, \$4, 84 Stat. 1497, deleted this exemption, thus broadening the Act's application to all types of tender offers.

315 U.S.C. $\$ \$ 78 a-h h$ (1964) [hereinafter referred to as Exchange Act].

$4 I d . \$ \$ 78 \mathrm{~m}(\mathrm{~d})-(\mathrm{e}), 78 \mathrm{n}(\mathrm{d})-(\mathrm{f})$ (Supp. V, 1970). In addition, the Act amended Exchange Act $\$ 12(i)$, id. $\$ 78 l(i)$, "to make clear that the authority and responsibility to administer and enforce the new disclosure provisions .... insofar as they apply to the securities of banks, will be vested in the various Federal banking agencies rather than in the Securities and Exchange Commission." S. REP. No. 550, 90th Cong., 1st Sess. 7 (1967).

515 U.S.C. $\$ 78 l$ (1964).

6 Id. $\$ \$ 78 \mathrm{~m}(\mathrm{~d})(5)(\mathrm{A})-(\mathrm{D})$ (Supp. V, 1970), redesignated $\$ \$ 78 \mathrm{~m}(\mathrm{~d})(6)(\mathrm{A})-$ (D) by Act of Dec. 22, 1970, Pub. L. No.'91-567' \$1 (b), 84 Stat. 1497; 17 C.F.R. $\$ 240.13 \mathrm{~d}-4$ (1971). Exchange Act $\$ 13(\mathrm{e}), 15$ U..S.C. $\$ 78 \mathrm{~m}(\mathrm{e})$ (Supp. V, 1970), makes unlawful any purchases by an issuer of its own securities in contravention of any rules promulgated thereunder by the Securities and Exchange Commission (Commission) to prevent fraudulent, deceptive, or manipulative acts. Rule 13e-1, 17 C.F.R. \$240.13e-1 (1971), requires disclosure of background information when repurchases are made while a tender offer is outstanding. Proposed rule $13 \mathrm{e}-2$, SEC Securities Exchange Act Release No. 8930 (July 13, 1970), 35 Fed. Reg. 11,410 (1970), would place price and volume limits on repurchases undertaken at any time. 
The disclosure required went beyond mere identification of the acquirers to include pertinent details of the actual transactions involved. ${ }^{7}$ Because disclosure requirements are placed on those who are already large shareholders rather than those who may acquire stock at some future date, section 13 (d) has the potential to affect greatly the internal distribution of corporate power. Both during the debate over the Williams Act and since that time, however, the section has been generally ignored-in part because of the drama surrounding the accompanying tender offer legislation, ${ }^{8}$ and in part because of its limited impact at the ten percent level. ${ }^{9}$

No consistent, workable rationale has been developed to guide the application of this section, despite its broad impact on shareholder attempts to exert control over corporate management. The decision of the Court of Appeals for the Seventh Circuit in Bath Industries, Inc. $v$. $B l o t,{ }^{10}$ the first reported instance of a contested suit involving the disclosure requirements of section 13 (d) outside the context of a tender offer, ${ }^{11}$ manifests the confusion surrounding application of the section. The recent passage of Public Law 91-567,12 an act which inter alia amended section 13 (d) by lowering the level of equity security ownership triggering the disclosure requirements from ten percent to five percent, broadens the section's impact and makes even more pressing the need to come to grips with the confusion.

This Comment will suggest that while the potential impact of section 13(d) was never adequately explained or discussed prior to enactment, Congress did articulate its underlying purpose: giving notice to investors of potential changes in corporate management, thus allowing the market to adjust its evaluation of the corporation's worth. Accordingly, this Comment will argue that section 13(d) was intended as a broad disclosure provision exposing every rapid, large-scale aggregation of equity securities, regardless of the method or the purpose of

715 U.S.C. $\$ \S 78 \mathrm{~m}$ (d) (1) (A)-(E) (Supp. V, 1970); 17 C.F.R. $\$ \$ 240.13 \mathrm{~d}-2$ to -101 (1971).

8 This is evidenced by the depth of interest in the subject. See note 2 supra.

9 Through June 1970 the Commission had received a total of only 542 filings under $\S 13(\mathrm{~d})$. Hearings on H.R. 4285, S. 3431, \& S. 336 Before the Subcomm. on Commerce \& Finance of the House Comm. on Interstate \& Foreign Commerce, 91 st Cong., 2d Sess. 4 (1970) (Memorandum of the Commission). Of these, 160 had been filed within the preceding 5 months. See Hearings on $S .336$ \& $S$. 3431 Before the Subcomm. on Securities of the Senate Comm. on Banking \& Currency, 91st Cong., $2 \mathrm{~d}$ Sess. 9 (1970) (testimony of Commission Chairman Hamer $H$. Budge). Those persons directly affected at the $10 \%$ level were apparently either few in number or little desirous of appearing before the subcommittees to object. But many objections were voiced when the disclosure level was to be lowered to $5 \%$. See sources cited note 97 infra.

10427 F.2d 97 (7th Cir. 1970).

11 A subsequent district court case has also been reported. GAF Corp. v. Milstein, [Current] CCH SEC. L. REP. 792,975 (S.D.N.Y. Mar. 22, 1971) (discussed at notes 89-91 infra \& accompanying text). One Commission enforcement proceeding was brought against a group which included Madison Square Garden Corp., but was terminated by a consent decree prior to a hearing on the merits. SEC v. Madison Square Garden Corp., [1969-1970 Transfer Binder] CCH FEd. SEc. L. ReP. \92,649 (S.D.N.Y. Apr. 29, 1970).

12 Act of Dec. 22, 1970, Pub. L. No. 91-567, 84 Stat. 1497. 
accumulation. Following this analysis, the Comment will suggest that the Seventh Circuit, endeavoring to dilute the advantage disclosure affords incumbent corporate management against outside control suitors, has limited application of the section to a narrower class than intended by Congress. The effect of this narrowing is to take away intended investor protection, while barely reducing management advantage.

\section{The Williams Act}

\section{A. The Statutory Scheme}

Section 13(d) (1) of the Exchange Act now provides:

Any person who, after acquiring directly or indirectly the beneficial ownership of any equity security . . . is directly or indirectly the beneficial owner of more than 5 per centum of such class shall, within ten days after such acquisition, send to the issuer of the security at its principal executive office, by registered or certified mail, send to each exchange where the security is traded, and file with the Commission, a statement containing such of the following information, and such additional information, as the Commission may by rules and regulations prescribe as necessary or appropriate in the public interest or for the protection of investors . . . . ${ }^{13}$

The disclosure required includes the background and identity of the acquirers, the source of their financing, the size of their shareholdings, information as to any "contracts, arrangements, or understandings with any person with respect to any securities of the issuer," and, if the purpose of the acquisition is "to acquire control of the business," any plans or proposals to make major changes. ${ }^{14}$ The class of persons subject to the disclosure requirements of section 13 (d) (1) also includes those defined in section $13(d)(3)$ :

When two or more persons act as a partnership, limited partnership, syndicate, or other group for the purpose of acquiring, holding, or disposing of securities of an issuer, such syndicate or group shall be deemed a "person" for the purposes of this section. ${ }^{15}$

${ }^{13} I d$. $\$ 1$ (a), amending 15 U.S.C. $\$ 78 \mathrm{~m}$ (d) (1) (Supp. V, 1970). The discussion of $\$ 13$ (d) in this Comment will be in terms of the Williams Act as amended, with a $5 \%$ disclosure level. The only deviation from this format will be in the discussion of Bath Industries, Inc. v. Blot, 427 F.2d 97 (7th Cir. 1970). Text accompanying notes 58-85 infra. The discussions of the Williams Act's rationale and the nature of its ramifications are valid for either a $10 \%$ or $5 \%$ disclosure level.

1415 U.S.C. $\$ \$ 78 \mathrm{~m}$ (d) (1) (A)-(E) (Supp. V, 1970).

$15 I d . \S 78 \mathrm{~m}(\mathrm{~d})(3)$. 
Section 13(d) (6) then provides exemptions from this disclosure scheme for acquisitions made by means of exchange offers under the Securities Act of $1933,{ }^{16}$ acquisitions by the issuer of a security, ${ }^{17}$ and

(B) any acquisition of the beneficial ownership of a security which, together with all other acquisitions by the same person of securities of the same class during the preceding twelve months, does not exceed 2 per centum of that class;

(D) any acquisition or proposed acquisition of a security which the Commission, by rules or regulations or by order, shall exempt from the provisions of this subsection as not entered into for the purpose of, and not having the effect of, changing or influencing the control of the issuer or otherwise as not comprehended within the purposes of this subsection. ${ }^{18}$

Pursuant to rulemaking power granted by section $13(\mathrm{~d})(1)$, the Securities and Exchange Commission has promulgated rules 13d-1 through $13 \mathrm{~d}-4$, covering the filing of the statement, amendments to the statement, computation of the percentage of beneficial ownership of a class of securities, and an exemption from filing of amendments where preemptive subscription rights to the stock of an issuer are exercised by a shareholder whose holdings were greater than five percent on the date of enactment. ${ }^{19}$

Thus at least in the case of an individual, the disclosure requirements are mechanically triggered by an acquisition susceptible of documentary proof, and reporting is required within a fixed period of time. Only two situations within the statute require examination of the subjective nature of the term "purpose." The first, the discretionary exemption under section 13(d)(6)(D), has not arisen because the Commission has not yet promulgated any exempting rules based on purpose to affect control. ${ }^{20}$ The second provision incorporating "purpose" into the triggering mechanism, section $13(\mathrm{~d})(3)$, is more trouble-

16 Exchange Act $\$ 13$ (d) (5) (A), 15 U.S.C. $\$ 78 \mathrm{~m}$ (d) (5) (A) (Supp. V, 1970), redesignated $\$ 13$ (d) (6) (A) by Act of Dec. 22, 1970, Pub. L. No. 91-567, §1(b), 84 Stat. 1497.

17 Id. $\$ 13$ (d) (5) (C), 15 U.S.C. $\$ 78 \mathrm{~m}$ (d) (5) (C) (Supp. V, 1970), redesignated $\$ 13$ (d) (6) (C) by Act of Dec. 22, 1970, Pub. L. No. 91-567, §1(b), 84 Stat. 1497. Section 13 (e) prohibits issuer purchases generally, except in accordance with Commission rules. See note 6 stpra.

18 Exchange Act $\$ \S 13$ (d) (5) (B), (D), 15 U.S.C. $\$ \$ 78 \mathrm{~m}$ (d) (5) (B), (D) (Supp. $V, 1970$ ), redesignated $\$ \$ 13$ (d) (6) (B), (D) by Act of Dec. 22, 1970, Pub. L. No. 91-567, \$1(b), 84 Stat. 1497.

19 SEC Securities Exchange Act Release No. 9060 (Jan. 18, 1971), 36 Fed. Reg. 976 (1971), antending 17 C.F.R. $\$ \$ 240.13 d-1$ to -4 (1971).

20 The only exemption under this section, rule 13d-4, SEC Securities Exchange Act Release No. 9060 (Jan. 18, 1971), 36 Fed. Reg. 976, 977 (1971), amending 17 C.F.R. $\$ 240.13 \mathrm{~d}-4$ (1971), operates only to relieve persons already owning more than $5 \%$, who acquire additional securities through certain preemptive subscription rights and is conditioned upon a filing pursuant to $\$ 16(\mathrm{a})$. 
some. It defines as a "person" any two or more persons who act together as a group "for the purpose of acquiring, holding, or disposing of securities of an issuer." In this instance, the normal evidentiary problems associated with the search for a "purpose" are compounded by the difficulty involved in reading this definition into section 13 (d) (1), the basic disclosure provision. Rarely do groups coalescing to exert control formalize their ties prior to buying securities, yet that appears to be the situation anticipated by the statutory definition of a group required to file. When the inquiry focuses instead on more common situations where relationships are subject to change and less formal, and where the acquisition of securities may predate the relationship, the words of the statute provide little guidance in determining when disclosure is appropriate. A mechanical insertion of the definition of a group into the text of section 13 (d) (1) suggests that disclosure is conditioned upon first, the existence of two or more persons acting as a group, secondly, acquisition by the group of the beneficial ownership of an equity security, and thirdly, total beneficial ownership of more than five percent of that class of securities following the acquisition. ${ }^{21}$ This problem of applying the statute to a group, along with difficulties in discerning the purpose of section $13(\mathrm{~d})$, are manifest in the Bath decision.

The breadth and depth of section 13 (d) are illustrated by comparing its provisions with other disclosure requirements imposed on shareholders by the Exchange Act. Section 14(d), the other provision added by the Williams Act, requires disclosure of the information enumerated in section 13 (d) (1) by any person launching a tender offer which, if consummated, would raise his ownership above the same five percent triggering level. ${ }^{22}$ While requiring disclosure before acquisition of the securities, section 14(d) covers a much narrower class because it excludes those within section 13 (d) who acquire their ownership in any manner other than a tender offer and includes individuals outside section 13 (d) only in the rare instance when they attempt to reach the five percent level of ownership through a tender offer and fail. ${ }^{23}$ Insofar as one accepts the thesis that tender offers are launched only by those with an intention to assert control immediately, section $13(d)$ sweeps much more widely than section $14(\mathrm{~d})$, requiring disclosure from persons hav-

21 Compare $\S 13(\mathrm{~d})(1)$ with $\$ 13(\mathrm{~d})(3)$, 15 U.S.C. $\$ \S 78 \mathrm{~m}$ (d) (1), (3) (Supp. $\mathrm{V}$, 1970).

22 Act of Dec. 22, 1970, Pub. L. No. 91-567, §3, 84 Stat. 1497, amending 15 U.S.C. $\$ 78 n(d)(1)$ (Supp. V, 1970).

23 Thus, a person who has successfully completed a tender offer for more than $5 \%$ of an issuer's outstanding securities will have disclosed twice: once at the time of the tender offer, pursuant to $\$ 14$ (d) (1), and again when the securities are taken up, pursuant to $\$ 13$ (d) (1). Under the Bath decision, $\$ 13$ (d) would cover even an unsuccessful tender offer when used by a group of stockholders owning more than $10 \%$ (now $5 \%$ ) of the outstanding stock, because, regardless of stuccess or failure, disclosure by such a group is required when the members agree to act in concert to acquire additional shares. See text accompanying notes 73-75 infra. 
ing no control motive ${ }^{24}$ and regardless of the method of acquisition. The other disclosure requirement imposed on shareholders by the Exchange Act may also be profitably compared with section $13(\mathrm{~d})$. In the simplest case covered by the original section 13 (d), individual acquisition of the beneficial ownership of ten percent of a class of equity securities, disclosure of the fact of ownership would also be required by section $16(\mathrm{a}),{ }^{25}$ which is primarily keyed to recovery of profits from insiders trading in securities. But the latter section is inapplicable below the ten percent level, and requires only disclosure of the fact of ownership, not the detailed and extensive information required under section $13(d)$. Thus by comparison to section $14(d)$, section $13(d)$ covers a broader field of purchases and has a weaker correlation with actual intention to control. By comparison to section 16(a), section 13(d) probes more deeply, eliciting detailed information about the acquirer helpful in assessing any potential use of the acquisition to assert control. Falling thus between these two, the language of section 13 (d) suggests that its purpose is neither disclosure from those attempting to gain corporate control nor disclosure from those attempting to manipulate securities for market profits.

The following sections will analyze the development of the rationale and mechanics of section $13(\mathrm{~d})$ and show that Congress, while preoccupied with protecting shareholders and investors affected by a tender offer takeover bid, intended through section 13 (d) to bring to the public eye every rapid accumulation of securities which, because of its size and unified control, carries the potential to affect the control of a corporation, and through that control, the market's valuation of the issuer's securities. After examining the legislative history of section 13(d), this Comment will argue that the overall purpose of section 13(d) requires a broad reading of its language to eliminate the requirement of either an acquisition or intent to acquire subsequent to formation of a

24 The exemption provided in $\$ 13(d)(6)(D)$ does not modify the general statutory scheme of ignoring intention to assert control. Although $\$ 13$ (d) (6) (D) permits the Commission to promulgate rules exempting certain acquisitions "as not entered into for the purpose of" influencing control of the issuer, this section does not contemplate a general exception for all cases where no control motive exists. First, if Congress desired the statute to apply only to control cases, it could have incorporated a general exemption instead of relying on the Commission's rulemaking power. This reliance indicates that Congress intended that the Commission, in its discretion, promulgate rules based on objective criteria and applying to certain limited cases. This conclusion is buttressed by the differing disclosure requirements in control and non-control cases under $\$ 13$ (d) (1). Text accompanying note 14 supro. Secondly, even if the Commission should provide a general exception in non-control cases, the acquirer's burden of proving a lack of control motive and the Commission's limited resources for such determinations would probably result in the actual exemption of few acquisitions. Finally, the Commission has not, in fact, granted any exemptions or laid down any rules based on the lack of a control motive. Text accompanying note 20 supra. It appears that the enactment was designed to require disclosure whenever a potential for control exists, leaving to investors the task of assessing the probability and impact of its assertion.

2515 U.S.C. $\$ 78 \mathrm{p}$ (a) (1964). This section is concerned with security market values rather than control per se. See Feldman \& Teberg, Beneficial Ownership Under Section 16 of the Securities Exchange Act of 1934, 17 W. RES. L. REv. 1054 (1964). Compare Exchange Act $\$ 3(\mathrm{a})(9)$ with $\$ 13$ (d) (3). 
group whose members individually hold securities which, when cumulated, amount to more than five percent of the class outstanding.

\section{B. Historical Perspective}

In the first session of the Eighty-ninth Congress, Senator Harrison Williams of New Jersey introduced S. $2731,{ }^{26}$ a bill which would have amended sections 10 and 16(a) of the Exchange Act ${ }^{27}$ to require disclosure prior to the acquisition of more than five percent of a class of equity securities registered under section 12 of the Exchange Act. ${ }^{28}$ The floor speech he gave in support of the bill was directed primarily against actual corporate takeovers, ${ }^{29}$ but Senator Williams recognized that his bill would also require that "any substantial accumulation of shares of a company registered under that act must be preceded by the filing of public information . . . ." s0 Although the advance disclosure provision did not survive, Senator Williams at that time saw disclosure of the accumulation as "the only way that corporations, their stockholders, and employees can be adequately prepared in advance to meet the threat of the takeover specialist." ${ }^{31}$ Filling out the rationale for his proposed scheme, he noted that restricting disclosure to cases involving tender offers would leave "gaps":

26 S. 2731, 89th Cong., 1st Sess. (1965).

2715 U.S.C. $\$ \$ 78 \mathrm{j}, 78 \mathrm{p}$ (a) (1964). Section $16(\mathrm{a})$ requires officers, directors, and beneficial owners of more than $10 \%$ of a class of equity securities of an issuer registered under $\$ 12$, within 10 days after attaining such status, to file with the Commission and any national exchange upon which the securities are registered a statement giving the "amount of all equity securities of such issuer of which he is the beneficial owner." Id. $\$ 78 \mathrm{p}(\mathrm{a})$. Section $16(\mathrm{~b})$, id. $\$ 78 \mathrm{p}(\mathrm{b})$, causes any profit from the sale and purchase of any security of the issuer within a 6 month period to "inure to and be recoverable by the issuer." The Commission subsequently objected to adding to $\$ 16$ (a) the $5 \%$ disclosure provisions of $S .2731$ because of the effect on the provisions for short-term profit recovery. 112 CoNG. REC. 19,004 (1966) (Memorandum of the Commission in remarks of Senator Williams).

28 The general scheme of $S$. 2731 required ongoing disclosure under $\$ 16(\mathrm{a})$ at the $5 \%$ level and added subsections (c) and (d) to $\$ 10$, requiring a notice be sent to the issuer and a statement filed with the Commission 20 days prior to either acquisition of beneficial ownership of more than $5 \%$ of any class of equity securities registered under the Exchange Act (proposed $\$ 10(\mathrm{c})$ ) or the making of a cash tender offer which, if successful, would result in ownership of more than $5 \%$ of such securities (proposed $\S 10(d))$. See 112 CoNG. REc. 19,003 (1966) (Memorandum of the Commission in remarks of Senator Williams). The statement was to contain substantially the same information now required under the Williams Act. See text accompanying note 14 sipra.

29 Near the beginning of his speech he stated:

In recent years we have seen proud old companies reduced to corporate shells after white-collar pirates have seized control with funds from sources which are unknown in many cases, then sold or traded away the best assets, later to split up most of the loot among themselves.

111 CoNg. REC. 28,257 (1965). (remarks of Senator Williams). He was later more cautious in using similar terminology. See Hearings on $S .510$ Before the Subcomm. on Securities of the Senate Comm. on Banking \& Currency, 90th Cong., 1st Sess. 123 (1967) [hereinafter cited as Senate Hearings on $S$. 510].

30111 CoNG. REc. 28,259 (1965) (remarks of Senator Williams) .

31 Id. 
Substantial open market or negotiated accumulations of shares may precede or accompany a tender offer or may otherwise relate to shifts in control of which investors should be aware. Where these accumulations are made in the open market there are real dangers of manipulation to the prejudice of investors, and in any case, the public is entitled to the protection resulting from advance disclosure of large-scale acquisitions. Therefore, to complete the picture, the same notice and disclosure provisions [as required before tender offers] also would apply to any person or group before he or it can acquire or increase ownership of such a security to more than 5 percent of the class by means other than a cash tender offer. ${ }^{32}$

He qualified his proposal in two ways to exempt acquisitions which posed no threat to corporate control. First, because "casual purchases and acquisitions which are not substantial should not be hindered," an exception would be provided for an acquisition which together with all others effected during the preceding twelve months would not exceed two percent of a class of securities. Secondly, the Securities and Exchange Commission would be empowered to grant exemptions if particular acquisitions would not "in any way change or influence the ultimate control of the corporation." 33 The latter provision, said the Senator, would "further protect the legitimate buyer who may be acquiring 5 percent of a corporation strictly for investment purposes and with absolutely no interest in affecting management policy." 34 Thus Senator Williams did not want to make proof of actual intent to assert control a prerequisite to the working of the disclosure provisions; yet he was reluctant to establish a rule requiring everyone-without exemption, and regardless of control motive-to disclose the required information upon acquisition of large amounts of a corporation's equity securities.

Senator Williams' proposals, however, soon underwent substantial revision. In particular, disclosure in advance of acquisition was eliminated. During the second session of the Eighty-ninth Congress, while S. 2731 was still pending, Senator Williams had printed in the Congressional Record a favorable memorandum on the bill from the Securities and Exchange Commission. ${ }^{35}$ This memorandum recommended that the provisions of the bill be added to sections 13 and 14 rather than sections 10 and 16, and laid out a scheme for the legislation which remains substantially the same in the present Williams Act. The Commission took the position that requiring advance notice of a pro-

$32 I d$.

$33 \mathrm{Id}$

$34 I d$.

35112 CoNG. REc. 19,003, 19,006 (1966) (Memorandum of the Commission in remarks of Senator Williams). 
posed acquisition would create difficulty, and argued instead that requiring "a statement [be] filed not more than 5 days after the acquisition would be less burdensome to beneficial owners who become subject to it." ${ }^{36}$ The Commission also made a similar recommendation for tender offer disclosure, but suggested an additional five day advance confidential filing with the Commission only. ${ }^{37}$

This effort to better balance the burdens involved in disclosure actually causes chaos for Senator Williams' proposed scheme if the underlying rationale is still assumed to be providing notice to the shareholders, management, and employees of a corporation of an outstanding intention to acquire a potentially controlling block of securities. Rather than being informed of impending purchases to facilitate action before consummation of the transaction, these classes were to be informed only of a fait accompli except insofar as a buyer was unable to complete his acquisitions program within ten days (the figure later adopted) of the time he exceeded the specified level. Senator Williams' original rationale being inadequate to support the disclosure requirement, one must look to subsequent legislative history for an explanation of the perceived value of after-the-fact disclosure.

\section{Later History of the Williams Act}

S. 2731 was not enacted, but the next year Senator Williams reintroduced the bill as S. $510,{ }^{38}$ the only important change being an increase from five to ten percent in the level of stock ownership triggering the disclosure requirements. When he introduced the bill, Senator Williams commented on the terms which were to become section 13(d) :

While some people might say that this information should be filed before the securities are acquired, disclosure after the transaction avoids upsetting the free and open auction market where buyer and seller normally do not disclose the extent of their interest and avoids prematurely disclosing the terms of privately negotiated transactions. ${ }^{39}$

${ }^{36} I d .19,004$. The Commission added, "Indeed, we envision some types of situations in which compliance with an advance notice requirement would be impossible, such as acquisitions by inheritance or by gift of which the recipient had no advance notice." Id. Not only would advance disclosure often be impossible, but in many cases it would be misleading: a putative purchaser could decide against the acquisition after filing; other investors could be induced into selling or buying on the basis of the filer's initial intention. The requirement as enacted was filing within 10 days after acquisition. 15 U.S.C. $\$ 78 \mathrm{~m}$ (d) (1) (Supp. V, 1970).

37112 CoNG. REc. 19,005 (1966). This requirement was eventually dropped in favor of simultaneous reporting and announcement of the tender offer. 15 U.S.C. $\S 78$ (d) (1) (Supp. V, 1970).

38 S. 510, 90th Cong., 1st Sess. (1967); see 113 Cong. Rec. $854-57$ (1967) (remarks of Senator Williams).

39113 Cong. Rec. 856 (1967) (remarks of Senator Williams). 
The Commission having previously given reasons why advance disclosure could not reasonably be required, ${ }^{40}$ Senator Williams now was explaining why advance disclosure should not be required. Contrary to the tender offer provisions and the initial scheme of the Williams Bill, the modified Williams Bill, as this statement indicates, was not designed to negate the normal inflationary market impact of rapid, large-scale securities purchases. The central problem now is developing a uniformly applicable rationale to justify the after-the-fact disclosure requirement for open market accumulations.

In his statement opening the hearings on S. 510,41 Senator Williams clearly distinguished from tender offers open market or privately negotiated purchases of securities as methods of obtaining control of a corporation. Stating that "anyone acquiring more than 10 percent of a class of an equity security" by either method would be required to disclose under the proposed legislation, he explicated the purpose for disclosure pursuant to each:

This is the only way that corporations, their shareholders and potential investors can adequately evaluate a tender offer or the possible effects of a change in substantial shareholdings. ${ }^{42}$

Thus in the tender offer context disclosure was deemed necessary to allow the stockholder to decide whether to sell or retain his securities; outside that context, post-acquisition disclosure was viewed as providing a basis for market re-evaluation of the corporation. Senator Williams' opening statement imputing this meaning to the new provision became sharpened as the hearings progressed.

Both Senator Williams and the Chairman of the Commission argued that section 13(d)'s disclosure was a necessary addition to the provisions of section 16 (a) ${ }^{43}$ because the acquisition of a substantial block of stock would enable a stockholder to "achieve the power to influence the management and control of the corporation . . . ."44 And, as the Chairman stated:

[Section 16(a)] does not give the public stockholders adequate information about the arrangements surrounding the acquisition or the purchaser's intentions with respect to the company. ${ }^{45}$

Disclosure had to be extensive to allow investors to discount possible changes in the issuer and the probability of change. Coverage had to

40 See note 36 supra.

41 Senate Hearings on $S$. 510, supra note 29, at 1-3.

42 Id. 2-3 (emphasis added).

43 Id. 24 (testimony of Commission Chairman Manuel F. Cohen); id. 36 (statement of Commission Chairman Manuel F. Cohen).

44 Id. 36.

$45 I d$. 
be broad to insure including all persons who might attempt to assert control. ${ }^{46}$ Although the sheer size of the block would cause some reevaluation of the issuer's securities, the number of shares and the acquirer's identity were already provided by section $16(\mathrm{a})$. The value of section 13 (d) lay in the disclosure of additional information concerning the acquirer, the acquisition transaction, and the acquirer's future plans. Such information would be valuable in calculating the possibility of, and the effect of, an exercise of control.

The criticisms leveled at S. 501 during the hearings are also illuminating. They illustrate that while objections were made to the entire bill ${ }^{47}$ and to section 13 (d) in particular, the Commission and Subcommittee rejected attacks which challenged the need for, or the practicality of, using the section to disclose the potential for change represented by any given accumulation. Arthur Fleischer, objecting to the bill on the grounds that "strong outside stockholder interests" were beneficial, criticized section 13 (d) as redundant vis-à-vis section $16(\mathrm{a})$ and harmful to the extent broader disclosure was provided. ${ }^{48}$ He added the observation that the disclosure of future plans from an outsider holding only ten percent of the stock would be of little value, and that in any case disclosure came after acquisition and too late to be used by an investor in the market. The latter statement, of course, was no longer responsive to Senator Williams' position. A letter from attorney Milton $\mathrm{H}$. Cohen offered a detailed criticism of the proposed legislation, including the redundancy of sections $16(\mathrm{a})$ and $13(\mathrm{~d}){ }^{49}$ He felt that section 13 (d) should be aimed at the "incipient situation or the situation where several persons act together in the acquisition of $10 \%$ " solely to eliminate the loophole for these two categories in section 16(a),

46 Acknowledging that requiring disclosure by every "person or group of persons" who acquired $10 \%$ of a class of stock could be dysfunctional in some situations, the Chairman stated that in cases of purchases for purely investment reasons, "[i]f we are given authority to deal with that problem, we will as we have with problems of this sort for the past 30 years." I $I$. 25. The Commission has not, however, promulgated any rules which would permit an acquirer of securities to omit disclosure on the basis of his purpose for acquiring those securities. See note 20 sitpra \& text accompanying note 19 supra. The policy of the Commission to require disclosure from any person acquiring the requisite amount of securities is reflected in Chairman Budge's testimony at the House hearings on S. 3431:

[Rep. Moss] : Does the Commission feel the normal reporting requirements should be applicable to the specialists or the market makers if the percent is reduced to 5 percent?

[Chairman Budge]: I think it is very important that it apply to both

Hearings on H.R. 4285, S. 3431, \& S. 336 Before the Subcomm. on Commerce \& Finance of the House Comm. on Interstate \& Foreign Commerce, 91st Cong., $2 \mathrm{~d}$ Sess. 58 (1970).

47 E.g., Senate Fearings on S. 510, supra note 29, at 136-39 (statement of Prof. Robert $\mathrm{H}$.' Mundheim, University of Pennsylvania Law School).

$48 \mathrm{Id}$. $128-29$ (Mr. Fleischer is a member of the New York Bar); see id. 65 (statement of Carlos L. Israels, member of the New York Bar); id. 161 (statement of Francis R. Schanck, First Vice President, Investment Bankers Ass'n of America). 49 Id. 246.

50 Id. 247. 
and that disclosure based on ownership alone, if any, should be limited to the identity and holdings of any associates of the acquirer and their present and desired representation on the issuer's board of directors. Mr. Cohen leveled the criticism that section 13(d)'s broad disclosure requirement would apply to all acquisitions made after adoption of the bill regardless of any intention to assert control, whereas pre-passage owners would not be required to disclose any information beyond their identity unless they were to take some steps toward influencing the corporation's management ${ }^{51}$-a result he found both anomalous and undesirable. For this reason, Mr. Cohen preferred application of section 13(d)'s broad disclosure provision only on the basis of an intention to assert control. ${ }^{52}$ The Chairman of the Commission replied directly to this criticism, setting forth again the rationale for the Act:

With respect to open market acquisitions, we disagree with the suggestion [of $\mathrm{Mr}$. Cohen] that disclosure be postponed until the acquirer actually assumes management or makes a tender offer, since disclosure at that point would come too late to inform the shareholders of the potential influence represented by the existence of a block of this size. We also do not believe that the situation of a person or group becoming a $10 \%$ shareholder is analogous to that of an existing $10 \%$ shareholder, since the latter's influence and intentions are presumably reflected in the corporation's policy and known to the other shareholders. ${ }^{53}$

The first sentence of this rebuttal presents a reading of the section which would require application to all cases of potential influence on control rather than to only those instances of an actual attempt to assert control or to situations where further stock acquisitions were seen as a threat to the market. The Chairman's goal was a disclosure requirement which would inform investors at the earliest possible moment of each new aggregation of voting power which represented a possibility that a change in the management of the corporation would shortly be effected by the holders of the new block of securities. Although management would be influenced by mere knowledge of the block's existence, the Chairman was focusing on the period, usually brief, between the accumulation and actual exercise, perhaps by threat of a proxy contest, of the voting power represented by the block. The second sentence explains the exemption of existing shareholders as consistent with the

51 "[T] only if he becomes a participant in a proxy contest under Rule 14a-11, i.e., seeks to take over management in some degree ...." Id.

$52 I d$.

53 Id. 201-02 (Supplemental Memorandum of the SEC with Respect to Certain Comments on S. 510 ) ; see id. 242 (statement by Cohen, Swados, Wright, Hanifin \& Bradford, Attorneys at Law, Buffalo, N.Y.). 
logic of post-acquisition, pre-control-assertion disclosure. Just as section 13(d) (6) (B) exempts acquisitions totaling less than two percent within a twelve month period ${ }^{54}$ on the theory that slow accumulations are unlikely to affect control, the exemption of existing shareholders reflects a judgment that longstanding pre-enactment accumulations would already have worked their effect, if any. Under the new rationale, no reason exists to treat old and new owners on a level of parity.

Thus the Subcommittee and the witnesses at the Senate hearings were aware that section 13 (d) as written, ${ }^{5 \check{5}}$ and as later enacted with a ten day period for disclosure, was to encompass every accumulation of more than ten percent of a class of equity securities registered under section 12 of the Exchange Act when that accumulation was rapid enough to fall outside the two percent de minimis exemption. ${ }^{56}$ The rationale developed for this scheme was that disclosure of the existence of such a block of securities would provide shareholders and investors with notice of the potential influence of this block on control of the issuer. In attempting to correlate the means and rationale of this section, the conclusion is compelled that the drafters believed that the speed with which such a block is accumulated is sufficiently related to subsequent attempts to influence the control of a corporation to justify this scheme of disclosure rather than some other scheme based on actual intent to assert control. The decision to require disclosure of all such blocks regardless of any control motive furthers an intent that the class of shareholders and other investors felt to be in need of protection from the vicissitudes of takeovers were to be so protected by being given the opportunity to react to the mere possibility of such an intent in addition to the actuality thereof. Unless management is considered the sole beneficiary of this disclosure, a proposition vehemently denied after $\mathrm{S}$. 510 was introduced, ${ }^{57}$ those receiving the information have no effective

54 Exchange Act $\$ 13$ (d) (5) (B), 15 U.S.C. $\$ 78 \mathrm{~m}$ (d) (5) (B) (Supp. V, 1970), redesignated $\$ 13$ (d) (6) (B) by Act of Dec. 22, 1970, Pub. L. No. 91-567, \& 1(b), 84 Stat. 1497.

55 No further changes were made in $\$ 13(\mathrm{~d})$, and no further attempts were made to refine the rationale for the disclosure provisions. The House Subcommittee hearings, Hearings on H.R. 14475 \& $S .510$ Before the Subcomm. on Commerce \& Finance of the House Comm. on Interstate \& Foreign Commerce, 90th Cong., 2d Sess. (1968), focused on specific objections to other parts of the Act by interest groups and related federal agencies; the relevant portions of the House Committee Report, H.R. REP. No. 1711, 90th Cong., 2d Sess. (1968), and Senate Committee Report, S. ReP. No. 550, 90th Cong., 1st Sess. (1967), offer little additional assistance. No significant floor debate took place before the bill was enacted on July $29,1968$.

50 The legislative history of Pub. I. No. 91-567, lowering the level of disclosure to $5 \%$, is similarly devoid of further explanation. The lower disclosure level's function appears to be to flush out persons who acquired $9 \%$ of an issuer's outstanding securities through open market purchases prior to making a tender offer. See S. REP. No. 1125, 91st Cong., 2d Sess. 3 (1970); Hearing to Ascertain the Views of Hamer $H$. Budge, Chairman of the Securities and Exchange Commission, on Problems in the Securities Industry Before the Subcomm. on Securities of the Senate Comm. on Banking \& Currency, 91st Cong., 1st Sess. 15 (1969).

57 See, e.g., S. Rep. No. 550, 90th Cong., 1st Sess. 3 (1967) ; 113 Cong. Rec. 24,664 (1967) (remarks of Senator Williams). 
means at their disposal to prevent the assertion of control. Rather, they are being supplied with information necessary to adjust for that possibility in their valuation of the corporation for investment purposes. Each item of information required-number of shares acccumulated, the acquirer's identity, his mode of financing, and whether his intent is to acquire control-enters into the calculus in computing the probability of a change in the management of the issuer due to the new block position, and thereby influences the investor's decision whether to keep constant, decrease, or increase his holdings in the issuer.

In terms of protection for investors, then, the method of aggregation is not vital, but rather the existence of a new aggregation itself. If five percent ownership of a class of securities is deemed the point at which disclosure is necessary for this rationale, the point set by the amended Williams Act, then there is little distinction between a market purchase of six percent and the grouping together of three previously independent shareholders, each owning two percent. In each instance a new block of securities exceeding the critical size has become subject to a common control and direction. The latter block is not similar to one held prior to passage, and thus exempt from disclosure, because the aim of section $13(\mathrm{~d})$ is disclosure of new aggregations which present the possibility of a change. The logic of the Act assumes that longstanding accumulations will have already effected their influence, and that slowly acquired blocks do not represent a control threat. All new, rapidly acquired accumulations are within the disclosure requirements because the ability to influence control has been achieved, and only recently.

\section{Bate Industries, Inc. v. Blot}

The decision of the Seventh Circuit in Bath Industries, Inc. $v$. Blot ${ }^{58}$ resulted in the first construction of section 13 (d) outside the context of a tender offer. ${ }^{59}$ The Bath controversy arose from the efforts of several shareholders of Bath Industries, Inc., to obtain control of the corporation by pooling their voting interests. ${ }^{60}$ Besides having

58427 F.2d 97 (7th Cir. 1970), aff'g 305 F. Supp. 526 (E.D. Wis. 1969).

59 See note 11 supra. The only provisions of $\S 13$ (d) incorporated in the $\$ 14$ (d) tender offer provisions relate to the nature of the information to be disclosed. See Exchange Act \$14(d) (1), 78 U.S.C. \$78n(d) (1) (Supp. V, 1970), as anended, Act of Dec. 22, 1970, Pub. L. No. 91-567, § 3, 84 Stat. 1497.

60 The controversy occurred at a time when Bath Iron Works, a Bath Industries subsidiary, was a competitor for a contract described by the Seventh Circuit as possibly "the largest shipbuilding contract ever awarded by the United States Navy." 427 F.2d at 104. The preliminary injunction against the defendants was sustained on the grounds that

the district court could have properly concluded that the adverse effects on Bath's position in the [contract] competition of a timely Williams Act disclosure would have been significantly less than the adverse effects of a disclosure coming after this action was filed and after the defendants had already acquired sufficient Bath stock to make the change in management a near certainty.

Id. at 113. 
purchased a substantial number of additional shares in support of their efforts, the defendants had held over ten percent of Bath's voting shares prior to any agreement to act together. Yet, as of the time management brought suit to prevent this attempt no statement complying with the requirements of section 13 (d) had been filed by any of the defendants. Given such a complete disregard of the requirements, the court had substantial freedom in construing the section because almost any conceivable interpretation would have resulted in finding a violation.

Bath Industries is a Delaware holding company with business offices in Milwaukee, Wisconsin. Bath was created as a holding company in 1967 when one of its present subsidiaries, Bath Iron Works Corporation, was reorganized. In July 1968 Emmet Blot, a member of the Board of Directors of Bath and a shareholder since early 1966, indicated some dissatisfaction with William Kyle, the chief executive of Bath, and expressed the feeling that Kyle should be replaced. During August of that year he informed the Board of Directors of Bath of his belief that the corporation needed a new chief executive and that the office of the holding company should be moved to New York City. Although Blot found little support for his views among the members of the Board, by April of 1969 he had found potential allies in the president of Madison Fund, Inc., a registered, closed-end investment company, and the vice president of Donner Corporation, which acts as investing agent and nominee for the William Donner family. ${ }^{61}$ These two expressed an interest in purchasing Kyle's shares for either their corporations or themselves and a meeting involving these two, Blot, Kyle, and several other members of Bath's management was held in New York City on April 19. No offer to purchase the stock came out of the meeting. During the time between this meeting and the end of August, Blot endeavored to find more allies for an effort to gain control. He eventually enlisted the cooperation of several financial institutions, but at the same time revealed his maneuvering to Bath: another member of the Board of Directors learned indirectly that attempts had been made to gain the support of American Express, which operates a number of mutual funds. A series of meetings ensued as the two sides tried to reach an accommodation, but when no agreement seemed possible, management filed suit in federal district court alleging violation by nine specified defendants of several sections of the Exchange Act, including section $13(d)$.

The district court issued a temporary restraining order and then held an evidentiary hearing on a request for a preliminary injunction. ${ }^{62}$ After finding that jurisdiction to entertain the suit existed under section 27 of the Exchange Act, ${ }^{63}$ the court ruled that the defendants constituted a group which had probably violated section $13(d)$ and, weighing

61 Id. at 105.

62305 F. Supp. 526, 528-29 (E.D. Wis. 1969).

63 Id. at 535-37. 
the "balance of hardships," granted a preliminary injunction against proceeding with the plan to take control. ${ }^{64}$

The court's reasons for finding a violation were not fully developed, and its technique of stating disjoint findings leaves some room for doubt. The court merely stated that the defendants

constitute a "group" which has acted together for the purpose of acquiring or holding the securities of Bath, as such a group is defined by Section 13(d) (3) of the Williams Act . . . and which has beneficially owned, directly or indirectly, more than ten percent of Bath common stock and preferred stock. . . . The court concludes that the members of the group agreed to pool their voting interests in Bath securities and to act in concert to carry out their plan to obtain control of the corporation through the election of a new chief executive officer of their choosing and to increase the size of the Board of Directors of Bath. In addition to pooling their voting interests it appears that certain members of the group acquired additional shares of Bath in order further to insure the success of their plan. ${ }^{65}$

Notwithstanding the last sentence quoted, the court went on to conclude that the defendants should have complied with the provisions of section $13(\mathrm{~d})$ " [w] $\mathrm{w}$ ithin ten days after the group described above agreed to act together." 68 This statement indicates the district court's perception that the agreement to act together rather than the acquisition of additional securities constituted the triggering act for purposes of section $13(\mathrm{~d})$.

On appeal, the Seventh Circuit sustained the preliminary injunction and remanded the case to the district court for further proceedings. ${ }^{67}$ The parties, before the court of appeals, each argued that the legislative history supported their respective readings of the statute's requirements. The plaintiff cited the House report on the Williams Act ${ }^{68}$ to support a disclosure requirement at the time of formation if a group's members in combination held in excess of ten percent of the outstanding equity securities of a corporation; ${ }^{69}$ the defendants referred to statements evincing an intent to require disclosure of securities purchases. ${ }^{70}$ The court took a different perspective and found that the

64 Id. at $537-39$.

$65 I d$. at 537. In further support of his holding, the district judge took judicial notice of "the fact that Wisconsin is the most civilized state in the Union." Id. at 533 n.4.

66 Id. at 538.

67427 F.2d at 114. As often occurs in a struggle for corporate control, this decision ended the litigation and a settlement was announced on Nov. 4, 1970. 'Wall St. J., Nov. 4, 1970, at 16, col. 1 .

68 H.R. Rep. No. 1711, 90th Cong., 2d Sess. (1968).

69427 F.2d at 108-09. The case arose before the disclosure level was reduced to $5 \%$. See note 13 supra.

70 Id. at 109. 
purpose of the Act was to protect investors, including "investors in general as well as the stockholders of the specific corporation involved." 71 The court also noted Senator Williams' avowed intent "to avoid tipping the scales either in favor of management or in favor of the person making the takeover bids." 72

The parties having articulated what they felt to be the relevant statutory considerations, the court held that compliance with the disclosure provisions of section $13(\mathrm{~d})$ is required

when, but only when, any group of stockholders owning more than $10 \%$ of the outstanding shares of the corporation agree to act in concert to acquire additional shares. ${ }^{73}$

The court added an evidentiary presumption to this holding to offset the plaintiff's obvious difficulty in proving the existence of such an agreement by the group:

[O]nce it is shown that such a group has agreed to pursue a common objective, and once it is further shown that a member of the group has thereafter purchased additional shares of the corporation's stock, then a rebuttable presumption arises that such purchase was made pursuant to an agreement of the group as of that date to acquire shares in furtherance of its objectives. $^{74}$

The court thus ignored both of two possible readings of section 13 (d) when a group's existing holdings exceed ten percent-disclosure within ten days of formation, or disclosure within ten days after acquisition of additional shares ${ }^{75}$ - in favor of an interpretation that triggered disclosure in advance of the purchase but independent of any other concerted group activities in pursuit of control. Because of a superficial inquiry into both the purpose of the Williams Act and the mechanics of section $13(d)$, the court derived a simplistic reading of the legislative intent: protect investors without helping management.

The requirement of pre-acquisition disclosure rested upon a finding that although existing shareholders were free to discuss mutual concerns with respect to the corporation,

71 Id.

72 Id. (quoting 113 CoNG. REc. 24,664 (1967)).

$73 I d$. In the first footnote of the opinion, quoting $\$ 13(\mathrm{~d})$ "in relevant part," the court omitted all exemptions provided by $\$ 13$ (d) (5) except the $2 \%$ rule. See id. at 101-02 n.1. If this was intended to suggest that there must be an agreement to acquire at least $2 \%$ of the shares within a twelve month period it would narrow the impact of the decision greatly. It would not, however, change the rationale of the decision, and indeed it might narrow the class of shareholders required to disclose so much that the statute would be largely nullified.

74 Id. at 110.

75 See text accompanying note 21 supra. 
when such a group . . reaches the point where it decides to buy additional stock . . . full disclosure . . . will be required. ... [I]t is at this point that the need for the Act's protection becomes critical. ${ }^{78}$

This construction seems based upon a perceived statutory purpose to protect investors from the market impact of purchases of additional securities rather than the market impact of major shifts in corporate voting power and the attendant ability to influence management of the corporation. The latter would occur regardless of any additional acquisitions where previously independent shareholders pooled their shares in furtherance of a joint purpose. The origin of this fundamental error is in the Seventh Circuit's reading of "the overriding purpose" of the Act. The court felt that disclosure is necessary "when substantial shareholders or management undertake to acquire shares . . . for the purpose of solidifying their own position ...." 77 The analysis of the legislative history laid out in the first section of this Comment demonstrates, however, that the purpose of the Williams Act was to force disclosure from anyone gaining control of large blocks of securities. ${ }^{78}$ Thus, the court's construction cannot be supported by the legislative history.

Even if the court's view of section 13(d)'s purpose is accepted, its own decision recognizes the difficulty in fulfilling this purpose. According to the court:

Apart from the unlikely execution of a formal agreement by a group to acquire additional shares . . . proof of such an agreement to acquire would be difficult for anyone not privy to the group's plan. ${ }^{79}$

For this reason, any purchase made by a member of the group would be rebuttably presumed to be on behalf of the group and in furtherance of group goals. Although an argument could be made that a decision to acquire additional shares would precede the actual purchase by at least one day, a filing by the group ten days after a group purchase would not constitute a section 13(d) violation under the Seventh Circuit's decision. Speaking of the purchase date, the Bath court said the acquisition would be presumed to have been "made pursuant to an agreement of the group as of that date to acquire shares in furtherance of its objectives." ${ }^{80}$ Disclosure ten days after the purchase would not protect against market effects of the transaction. At the same time, if

76427 F.2d at 110.

77 Id. at 109.

78 See text accompanying notes $26-57$ supra.

70427 F.2d at 110.

$80 \mathrm{Id}$. (emphasis added). 
no purchases are made after formation of the group, disclosure will not necessarily be forthcoming, since the difficulty of proving the formation of an intent to acquire remains. Thus, the real effect of the Seventh Circuit's holding is to require disclosure only after additional purchases have been made, a result which effectuates neither the court's goal nor the purpose of the statute as stated by this Comment.

Further difficulty arises because the court's view of the rationale of the Williams Act cannot alter the delay between the triggering event and disclosure. ${ }^{81}$ Because disclosure lags behind the agreement to buy more shares by ten days, substantial purchases may follow the triggering event but be completed before disclosure, a sequence of events which precludes any forewarning of the possible market impact of the purchases. The existence of this lag underscores the fallacy of the Seventh Circuit's construction of section 13(d). Therefore, even assuming the court's reading of the underlying purpose to be correct, the mechanics of the Act make achievement of such a purpose impossible. This inconsistency reinforces the conclusion that the purpose was to forewarn of possible changes in corporate control, not to forewarn of possible market activity.

Part of the court's difficulty may have stemmed from its attempt to construe the statute without "tipping the scales" so as to benefit management. The court implicitly assumed the legitimacy of existing shareholders gathering to discuss issues relating to their corporation, even to the point of formulating a "determination to take over control of management." 82 The court's fear was that formulating a rule which would trigger disclosure from a shareholder group immediately upon formation would hamper such efforts by shareholders because management would be apprised of the existence of the dissident group and would be able to take prompt measures to thwart any actual attempts to acquire control. If this was the court's thinking, there is no reason other than the discarded market-impact rationale ${ }^{83}$ why disclosure should not be triggered only by actual purchases subsequent to the group organization, rather than by the mere formation of an intent to purchase.

81 See Exchange Act $\$ 13(d)(1), 15$ U.S.C. $\$ 78 \mathrm{~m}(\mathrm{~d})(1)$ (Supp. V, 1970).

82427 F.2d at 110 . The application of $\$ 13(d)$ to a group immediately upon formation as urged by this Comment may arguably conflict with the philosophy behind the exemption for solicitations of less than 10 persons contained in the proxy rules. 17 C.F.R. \$240.14a-2(a) (1971). Absent this exemption, Blot's conduct would conceivably require disclosure by virtue of the definition of a solicitation in rule $14 a-1$. Id. $\$ 240.14 a-1$. The easiest resolution of this conflict is to note that the 10 person exemption is merely a Commission rule promulgated pursuant to Exchange Act $\$ 14$ (a)'s general mandate. 15 U.S.C. $\$ 78 n(a)$ (1964). The absence of any substantial reference in the hearings or reports on the Williams Act to the proxy rules indicates that Congress' intent was to require disclosure in every instance within $\$ 13$ (d)'s logic. This most recent enactment in response to Congress' current view of the requirements of corporate democracy should take precedence over the older proxy regulations, even before considering the superiority of a statute over a rule. Cf. Comment, 71 Colun. I. Rev. 466, 472 (1971).

83 See text accompanying notes $26-31$ supra. 
Several commentators ${ }^{84}$ have suggested that the Bath result is an admirable balancing of interests because it provides disclosure before the takeover is completed, whereas if disclosure is delayed until "[a]fter the triggering purchase has been made, . . . the takeover may already be a fait accompli, thus nullifying the Act's goal of providing early disclosure." 85 But this argument assumes too much, because a shareholder group may be able to acquire control on the strength of its members' existing merged holdings without acquiring any additional shares. If the purpose of section 13(d) is to require disclosure of potential control changes, the aggregation of voting power in the shareholder group is a more critical point for disclosure than a decision to acquire additional shares to reinforce the group's position. Whether disclosure under the Bath holding comes within ten days of the group's decision to acquire more shares or within ten days after the acquisition, significant undisclosed control manuevers will be possible. Thus in Bath, if the original holdings of Blot and his allied mutual funds had been large enough to assert control, the corporation could have been radically altered without any advance disclosure to individual investors of the possibility of such a change. This result is directly contrary to the purpose of the Williams Act. The legislative history shows that Congress' intent was not the disclosure of market purchases but the disclosure of all instances of rapidly accumulated voting power.

The correct result in a shareholder group situation is to require disclosure within ten days of the formation of a group whose members' combined holdings exceed five percent of an issuer's securities. This would effectuate the Act's purpose of disclosing accumulations of large security blocks in order to give investors maximum warning of potential changes. An initial problem with such a suggestion is that the statutory construction necessary to produce such a result is somewhat forced. Disclosure upon formation would be achieved by holding that upon formation the group, as a distinct entity, acquires beneficial ownership of the individual members' shares, thus triggering section 13(d) (1)'s disclosure requirements. But section 13(d) (3)'s definition of a group for the purposes of the Williams Act is any "group [acting together] for the purpose of acquiring, holding, or disposing of securities." Triggering disclosure immediately upon formation would make the qualifying language following "group" in section 13 (d) (3) superfluous because any group acquiring beneficial ownership would have to disclose without further inquiry into whether its purpose was to acquire, hold, or dispose of securities. ${ }^{86}$ But an analysis of the Act indicates that section 13 (d) (3) was designed primarily for the situation

84 Comment, 45 N.Y.U.L. REv. 1136, 1141 (1970) ; BNA SEc. REg. \& L. REP. $\mathrm{B}-1, \mathrm{~B}-12$ (June 17, 1970) ("The court's decision is an admirable blend of theory and fact ....").

85 Comment, 45 N.Y.U.L. Rev. 1136, 1141 (1970).

${ }^{86}$ See id. 
where the group's members at the time of formation held no shares and sought to buy up control while escaping section 13 (d) (1) by limiting individual purchases to five percent. In the absence of an assumption of legislative perfection, the existence of redundant language in a specific application of the statute does not call for rejecting the construction which supports such an application. Section 13 (d)(3) can be read to require disclosure from a group before any subsequent purchases; ${ }^{87}$ the legislative intent strongly supports such a result. ${ }^{88}$

A federal district court, in GAF Corp. v. Milstein, ${ }^{89}$ deciding a "group" case distinguishable from Bath in that no subsequent purchases occurred, also ignored the legislative history. The Milstein court reasoned:

Legislative history is extremely useful for interpreting a statute when the Act's language is ambiguous. . . . [But] the specific statutory language [in section $13(\mathrm{~d})(3)$ ] is clear and compels the construction that the reportable event is the acquisition of the requisite amount of shares and not the mere formation of a group with a view to control. ${ }^{90}$

This statement, however, followed a declaration that the term "acquisition" is nowhere defined in the Williams Act, ${ }^{11}$ an admission which allows the reading suggested by this Comment. Subsequent court decisions should disregard the Seventh Circuit's holding and that in Milstein in favor of that construction of section 13 (d) urged by this Comment, which most comports with the entire Act's purpose.

Potentially more serious problems with this Comment's interpretation of section 13 (d) result from the effects of such a sweeping disclosure

87 See Comment, 71 CoLuM. L. REv. 466, 473 (1971) ("such a construction of the statute [is] permissible on its face"). The author, however, by giving great weight to the professed neutrality of the operation of the Act's provisions, concluded that such a result did not comport with the Williams Act's overall purpose.

88 See S. REP, No. 550, 90th Cong., 1st Sess. 8 (1967):

The group would be deemed to have become the beneficial owner, directly or indirectly, of more than 10 percent of a class of securities at the time they agreed to act in concert. Consequently, the group would be required to [disclose] . . . within 10 days after they agree to act together, whether or not any member of the group had acquired any securities at that time. This provision is designed to obtain full disclosure of the identity of any person or group obtaining the benefits of ownership of securities . . . .

Professor Loss originally supported this view of the statute, see $6 \mathrm{~L}$. Loss, SECuRITIES REgUlation 3664 (Supp. 1969), but has apparently changed his mind. See GAF Corp. v. Milstein, [Current] CCH FED. SEC. L. REP. \I92,975, at 90,607 (S.D.N.Y. Mar. 22, 1971). 1971).

89 [Current] CCH FEd. SEC. L. REP. \92,975, at 90,604 (S.D.N.Y. Mar. 22,

90 Id. at 90,607 .

81 Id. at 90,606. The district judge's holding that disclosure is not required absent actual post-formation purchases may result from using the erroneous marketimpact rationale for the statute in giving meaning to the term "acquisition." See id. at 90,609 . 
requirement. In addition to the defensive tactics presently available, ${ }^{92}$ management will have a powerful legal tool to use against any competing groups. Perhaps this result caused the Seventh Circuit to hinge disclosure on an event after formation of the group. In fact, the interpretation suggested by this Comment may have such a chilling effect as to preclude any efforts by existing shareholders to assert control. Any group that desired to assert control would have to file the required documents at the time of formation, because any subsequent purchases or actual efforts at control would alert management to seek immediate injunctive relief from a district court. ${ }^{93}$ Significant information regarding the takeover group would be publicly disclosed while management, absent any share transactions, ${ }^{94}$ could maneuver in relative secrecy. But Congress was well informed of the Williams Act's potential for harm, especially the harm in endeavoring to protect investors caught in a control fight by giving an additional tactical advantage to incumbent management. Even granting the sincerity of Senator Williams' concern with "tipping the balance," ${ }^{95}$ the legislative history compels the conclusion that Congress intended to force disclosure of potential control threats regardless of their form.

Another area in which a broad interpretation of section $13(d)$ could cause difficulty is the activities of large financial institutions. ${ }^{96}$ For example, a number of mutual funds with a common investment advisor could be considered subject to section 13(d) although individual fund holdings did not exceed five percent. Further, institutional investors "acting together" to influence management policy might fall within the definition of a "group." At the hearings on the Williams Act representatives of these institutions objected to disclosure. They

92 See, e.g., Fleischer \& Mundheim, supra note 2, at 321-23.

93 The relief granted in Bath was a preliminary injunction enjoining the defendants from proceeding with their plans to call a special shareholders' meeting and remove Kyle, the chief executive officer. 427 F.2d at 114 . As suggested by the Bath court, 427 F.2d at 111 n.7, other relief measures are available.

94 See note 6 supra.

95 But cf. $\S 13$ (d) (1): "Any person ... [ [required to disclose shall] send to the issuer of the security at its principal executive office, by registered or certified mail, send to each exchange where the security is traded, and file with the Commission [the information required by $\$ 13(\mathrm{~d})]$. . . " Although the latter two means of disclosure may be expected to provide adequate public dissemination, the first reflects a concern that incumbent management be the first to know. See also 6 L. Loss, Securities Regulation 3664-65 (Supp. 1969): "Perhaps the committees" silence [in response to the arguments against the wisdom of the Williams Act, see notes 47-51 supra \& accompanying text] .. . reflects some philosophical overtones here whose disquieting effect cannot be entirely removed."

${ }^{96}$ See Comment, 45 N.Y.U.L. REV. 1136, 1143 n.50 (1970). The magnitude of this aspect of the problem should not be underestimated. The Commission has compiled statistics from a representative sample of the largest corporations whose stock is traded on the New York, American, and over-the-counter exchanges, indicating that at least $10 \%$ of the stock of each of 348 of the 656 companies in the sample was held by institutional investors numbering 10 or fewer, and at least $15 \%$ of the stock of 182 of those companies was held by institutional investors numbering 5 or fewer. See SeCuRities \& ExChange Comm'N, Institutional INVEstor StUdy, H.R. Doc. No. 64, 92d Cong., 1st Sess., pt. 5, at 2844-45 (1971). 
maintained that disclosure would have undesirable consequences, and since mutual funds would never seek control, they and similar groups should not be covered, ${ }^{97}$ section 13 (d) being ultimately aimed at potential control situations.

But such arguments are no reason for a court either to adopt the Bath rule or to attempt to mold an exception for such institutions. Congress did not enact a general exception for institutions in response to the objections. Rather, the hearings on S. 3431 demonstrate a relative lack of sympathy for the potential difficulties with section 13 (d) of financial institutions and other dealers in large blocks of securities. Senator Williams, for example, dismissed the problem of the burden

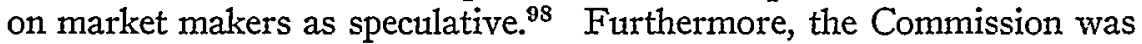
given ample authority to exempt financial institutions from the disclosure requirements of section 13 (d), or at least to mitigate any hardships. Section 13 (d) (6) (D) ${ }^{99}$ contained in the original Williams Act as section 13 (d) (5) (D), granted the Commission authority to exempt "any acquisition ... not entered into for the purpose of . . . influencing the control of the issuer . . . Section 13(d) (5), added in the recent bill which lowered the disclosure level to five percent, granted the Commission authority to allow a more simplified statement to be filed by a person acquiring the requisite amount of securities "in the ordinary course of his business." 100 According to the Report of the Senate Committee which added section 13(d) (5) to S. 3431:

97 See Hearings on S. 336 \& S. 3431 Before the Subcomn. on Securities of the Sentate Comm. on Banking \& Catrrency, 91st Cong., 2d Sess. 101, 102-03 (1970) (statement of Donald I. Calvin, Vice President, New York Stock Exchange); id. 110, 111-12 (statement of Richard B. Walbert, President, Nat'l Ass'n of Securities Dealers, Inc.) ; id. 114, 116-20 (statement of Craig Severance, Chairman of the Federal Securities Acts Committee, Investment Bankers Ass'n). Arguing that mutual funds would never seek control appears especially unpersuasive in light of the role played by several mutual funds in the Bath case. See 427 F.2d at 105-08. Although a fund would probably not seek control for itself, its buying power or already owned shares are available in a control struggle.

Indeed, the Commission itself-though reporting that "[i]nstitutions do not generally involve themselves directly in corporate decision-making . . ."-concluded a recent study with the observation that:

Some institutions have been actively and significantly involved in facilitating contested transfers of corporate control. In such cases, unlike ordinary corporate decision-making, the benefits to participating institutions may be more certain: in addition to trading and tendering profits, institutions may receive special inducements and benefits not made available to other shareholders of target companies.

Securities \& Exchange Comin'n, Instrututional Investor Study, H.R. Doc. No. 64, 92 d Cong., 1st Sess., pt. 5 , at 2849 (1971).

98 Hearings on S. 336, supra note 97, at 118 (reply of Senator Williams to Gordon L. Calvert, General Counsel, Investment Bankers Ass'n).

99 Exchange Act $\$ 13$ (d) (5) (D), 15 U.S.C. $\$ 78 \mathrm{~m}$ (d) (5) (D) (Supp. V, 1970), redesignated $\$ 13$ (d) (6) (D) by Act of Dec. 22, 1970, Pub. L. No. 91-567, \$1(b), 84 Stat. 1497.

100

The Commission. . . may permit any person to file in lieu of the statement required by $:[\$ 13$ (d) (1)] a notice stating the name of such person, the number of shares. . owned by him, the date of their acquisition and such other information as the Commission may specify, if it appears to the Commission that such securities were acquired by such 
Acquisitions by stock exchange specialists, over-the-counter marketmakers, and investment companies might well fall within the class of persons to which this amendment addresses itself. While not exempting such persons from reporting, this amendment will enable the Commission to make the reporting provisions less burdensome for them by removing the requirements which do not appear necessary to protect investors. ${ }^{101}$

Thus, the construction of section 13 (d) suggested by this Comment in order to provide the intended maximum protection to individual investors should not and need not have adverse effects on financial institutions engaged solely in securities trading.

\section{CONCLUSION}

Although the primary evils aimed at by Congress in passing the Williams Act were abuses of the cash tender offer device, the statutory mechanism created also requires disclosure whenever any rapid accumulation of voting power occurs. The goal was to give investors notice of the potential for change in control of a corporation so that a more accurate valuation of its securities might be possible. Thus, disclosure should be required any time a group of existing security owners whose combined holdings exceed five percent of the existing shares join together to act in furtherance of a common goal, because at that moment they have acquired the organizational efficiency and economic power to pose a control threat. A consistently rational interpretation of the statute's words to cover the shareholder group situation is impossible; disclosure within ten days of group formation is the construction of section 13 (d) most faithful to Congress' purpose and is the standard that courts should employ.

One must concede that such a broad disclosure provision will significantly aid incumbent management in thwarting changes; in fact, this aspect was a prominent source of objection to the entire Williams Act. There can be little doubt, however, that Congress, through its committees, was fully aware of the implications of section $13(\mathrm{~d})$ for corporate control struggles; a dysfunctional effect does not justify judicial abandonment of the statutory intent. Rather, if Congress is displeased with the substantial advantage given management, Congress may reconsider the wisdom of the Act and adopt remedial legislation:

person in the ordinary course of his business and were not acquired for the purpose of and do not have the effect of changing or influencing the control of the issuer nor in connection with or as a participant in any transaction having such purpose or effect.

Act of Dec. 22, 1970, Pub. L. No. 91-567, § 1(b), 84 Stat. 1497.

101 H.R. Rep. No. 1655, 91st Cong., 2d Sess. 5 (1970). 
either wholesale repeal or an attempt to carve out exceptions or special rules for particular groups is possible. ${ }^{102}$

Imperfect statutes working hardships on innocent classes frequently invite judicial creativity: to effect a minimum of undesirable consequences it may on occasion be necessary for the judiciary to lubricate the internal mechanics of a statute. In the process, statutory language may clearly be stretched, meaning given contrary to any vision of the legislation's framers. But license to construe so freely should not be taken inconsiderately; judicial resolution of difficulties in statutory language ought to be undertaken only with a well-developed awareness of and sensitivity to the problems the legislature attempted to resolve. Diverging from this standard in the Bath case, the Seventh Circuit has established a precedent which, if followed, will do little to aid the shareholder and much to further entrench management.

102 The recent passage of S. 3431, see note 12 supra, indicates, however, that such a reconsideration is unlikely. Congress has instead widened the scope of $\$ 13$ (d) by lowering the level of beneficial ownership triggering disclosure from $10 \%$ to $5 \%$. Nevertheless, Congress should reassess its policy. Section 13(d) does seem an unnecessarily harsh measure to correct takeover-related abuses. The present statute operates to disadvantage those seeking control of a corporation, including groups of existing shareholders, regardless of their intentions with respect to future management of the corporation. If Congress' genuine concern is protecting against situations where corporate "raiders" assume control and liquidate the corporation's assets in a manner detrimental to the remaining shareholders, creation of a federal remedy for waste of corporate assets would be a more efficient method than disclosure under $\$ 13(\mathrm{~d})$. 